\title{
Megakaryocyte Quantitation
}

\author{
LAURENCE A. HARKer \\ From the Department of Medicine, University of Washington School of \\ Medicine, Seattle, Washington
}

A B S TRACT A method is described for the quantitation of megakaryocytes. In this technic bone marrow sections obtained at the time of maximal marrow uptake of previously injected plasma bound ${ }^{59} \mathrm{Fe}$ are counted for radioactivity as well as the number of megakaryocytes and nucleated red cells. We calculated the total megakaryocytes by relating the ratio of megakaryocyte: radioactivity with the total marrow ${ }^{59} \mathrm{Fe}$ activity at the time of sampling. A multiple counting correction factor which is related to cell diameter and section thickness is required for quantitation of cell numbers from section material. The normal megakaryocyte number for the rat is $11.0 \times 10^{6} / \mathrm{kg}$, and 6.1 $\times 10^{6} / \mathrm{kg}$ for man.

\section{INTRODUCTION}

Measurements of thrombopoiesis are dependent upon accurate determination of the total megakaryocyte mass. The wide variation in reported estimates of megakaryocyte numbers, as much as 300 -fold (1-3), emphasizes the need for a different approach to their quantitation. For this purpose the method described in this paper was developed, based on the isotope-dilution principle, in which bone marrow is labeled with ${ }^{59} \mathrm{Fe}$ and then the number of megakaryocytes is related to the amount of radioactivity in individual sections of the marrow.

\section{METHODS}

The animals used were male Sprague-Dawley rats weighing $250 \pm 25 \mathrm{~g}$ with hematocrits ranging from 37 to $43 \%$ and platelet counts of $1.33 \times 10^{8} / \mu 1 \pm 0.19$. High

Dr. L. A. Harker is an instructor at the Division of Hematology, University of Washington, Seattle, Wash.

Received for publication 31 August 1967 and in revised form 20 October 1967. dose ${ }^{89} \mathrm{Fe}$ was given to three patients who had metastatic bronchogenic carcinoma and who were thought to have less than 2 yr of life expectancy. This selection of subjects was made because of the radiation exposure involved. These three patients were hematologically normal on the basis of peripheral blood counts, reticulocyte counts, platelet survival time, plasma iron turnover, and bone marrow aspirate examination. In addition, the normal range of the megakaryocyte: nucleated red cell ratio and the normal megakaryocyte diameter were measured in human bone marrow biopsies obtained from six female and nine male normal adult volunteers.

We added ${ }^{59} \mathrm{Fe}$ for marrow labeling to sterile, freshlydrawn plasma from subjects known to be free of hepatitis in proportions calculated not to exceed $50 \%$ transferrin saturation. This labeled plasma was injected intravenously in doses of about $20 \mu \mathrm{c}$ of ${ }^{59} \mathrm{Fe}$ for each rat and approximately $0.75-1.0 \mathrm{mc}$ for each of the three hematologically normal human subjects. This was calculated to give a maximal cumulative bone marrow exposure of approximately 50 rads, and produced no significant change in peripheral blood counts during the subsequent 6 months.

Bone marrow samples were obtained at the time of maximal marrow labeling; i.e., $6 \mathrm{hr}$ in the rat and 18$24 \mathrm{hr}$ in man. We took rat marrow from the femur as an intact column by removing the overlying bone with dental wire cutters and lifting the core of marrow tissue with a dental spoon excavator. These specimens, as well as samples of spleen and lung, were fixed in Zenker's solution ${ }^{1}$ for $2 \mathrm{hr}$. They were then washed, dehydrated, and blocked in paraffin. Sections were cut at $3 \mu$ thickness ${ }^{2}$ and mounted on coverslips. Human bone marrow biopsies were obtained from both posterior iliac crests with a 10 -gauge Silverman needle. ${ }^{3}$ After fixation in Zenker's solution, we decalcified the bone marrow core with $5 \%$ formic acid for at least $24 \mathrm{hr}$. Subsequent mounting and

$120 \mathrm{ml}$ of Zenker's solution ( $25 \mathrm{~g} \mathrm{~K}_{2} \mathrm{Cr}_{2} \mathrm{O}_{7}, 50 \mathrm{~g} \mathrm{HgCl}_{2}$ made to 1 liter with water), $2 \mathrm{ml}$ of formaldehyde, and $1 \mathrm{ml}$ of acetic acid freshly mixed just before use.

2 American Optical Company, Southbridge, Mass., 820 microtome.

3 Obtained from Becton-Dickinson \& Co., Rutherford, N. J. 
sectioning followed the outline given for animal narrow sections.

Six randomly chosen tissue sections were measured for ${ }^{50} \mathrm{Fe}$ activity in a low background gas-flow beta counter $^{4}$ to a statistical error of less than $1 \%$. Background averaged from 2 to $4 \mathrm{cpm}$, and net tissue section activity varied from 250 to $300 \mathrm{cpm}$ in the rat and $15-50$ $\mathrm{cpm}$ in human material.

After the determination of ${ }^{59} \mathrm{Fe}$ activity, the sections were stained overnight with Giemsa stain and then decolorized in $95 \%$ ethyl alcohol. We counted all megakaryocytes and nucleated red cells under light microscopy, ${ }^{5}$ using a micrometer grid in one eyepiece to ensure total coverage. The megakaryocytes usually contained characteristic granulated cytoplasm and a polylobulated nucleus, although portions of cells not containing nuclear material were recognizable as megakaryocytes and counted as such if they were larger than about $8 \mu$ in diameter. An equivalent number of splenic sections were also counted for megakaryocytes and ${ }^{50} \mathrm{Fe}$ activity. Because we saw megakaryocytes only rarely in sections of lung tissue, no counting was performed on them. To establish the range of the normal megakaryocyte: nucleated red cell ratio, at least 10,000 nucleated red cells were counted in duplicate from each of the 15 normal human marrow biopsies.

In serial tissue sections, megakaryocytes appeared as large, spheroidal cells extending through multiple sections (Fig. 1), composed of a central cut passing through the center of the sphere whose diameter represented the diameter of the sphere, and adjacent sections whose diameter measurements were analogous to "chord lengths" of a circle. The tissue sections were relatively thin $(3 \mu)$ compared to the diameter of the megalkaryocytes, so that only a portion of each megakaryocyte appeared in a single section (Fig. 1). Consequently, in serial sections of marrow the fact that a single megakaryocyte would be counted several times necessitated a correction for "multiple counting" error. The theoretical factor for such multiple counting is a function of the cell diameter and tissue section thickness, ${ }^{6}$ which necessitated the accurate determination of megakaryocyte diameter.

4 Lowbeta Counter, Beckman Instruments, Inc., Fullerton, Calif., Sharp Laboratory, made available through grant AMO 7898.

5 Photomicroscope, Carl Zeiss, Oberkochen, Germany.

6 When given: $d / t=i+f$; where $d=$ cell diameter; $t=$ thickness of the section; $i=$ integer portion of $d / t$; and $f=$ fractional remainder of $d / t$. A single cell appears in either $i+1$ or $i+2$ sections. The probability $\left(P_{t+1}\right)$ that a cell of diameter $d$ will appear in $i+1$ serial section is : $\left(P_{i+1}\right)=1-f$, and the probability $\left(P_{t+2}\right)$ that a cell of diameter $d$ will appear in $i+2$ serial section is : $\left(P_{1+2}\right)=f$. The average number of serial sections in which a cell of diameter $d$ will appear is: $(i+1)(1-f)+(i+2) f$, which is $i+f+1$ or $(d / t)+1$. It follows that the actual number of whole cells represented in the section $(N)$ is : $N=N^{1} /(d / t+1)$ where $N^{1}$ equals the number of cells enumerated in the section.

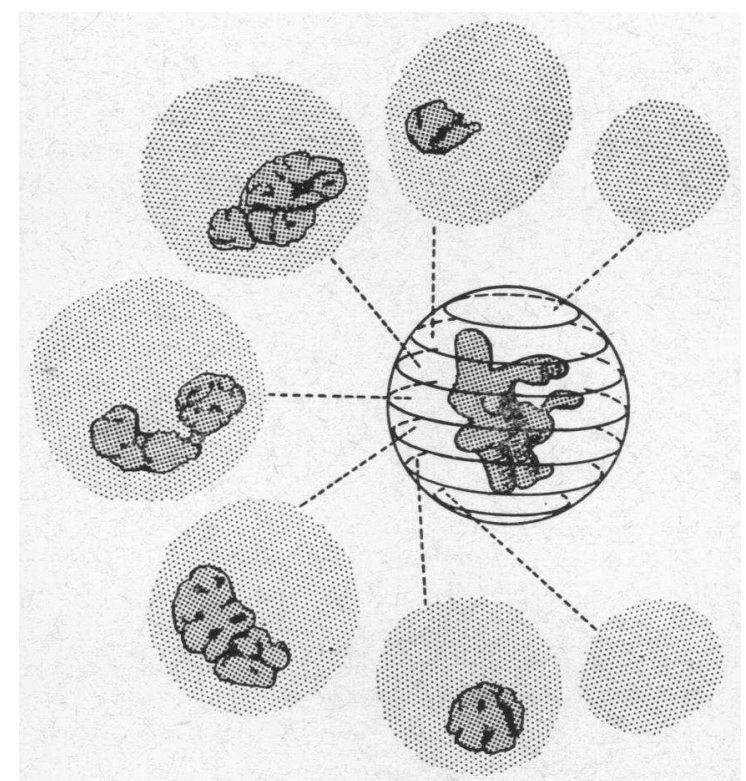

FIgURE 1 Serial sectioning of a megakaryocyte. A typical example of a megakaryocyte serially sectioned to illustrate the spheroidal character of the cell in sectioned marrow. The true diameter of the cell is obtained from the central section. The mean diameter of all the serial sections, "chord lengths," is $87 \%$ of the maximal diameter and the mean diameter of sections containing nuclear material is $93 \%$ of the maximal cell diameter.

From serial section studies of 50 megakaryocytes, the average diameter of all the sections through a single cell was shown to be $87 \%$ of the actual diameter. The average diameter measurement of sections containing nuclear material was $93 \%$ of the actual cell diameter. Accordingly, the mean megakaryocyte diameter was determined from planimetric measurments of nuclear-containing megakaryocytic cuts on random section photomicrographic enlargements and corrected by a factor of $1 / 0.93$ to give the true diameter estimate. In six animals, 346 marrow megakaryocytes were measured; and in humans, a total of 460 cells were measured from 18 subjects (Table I). Measurements of mean megakaryocytic diameter were almost

TABLE I

Megakaryocyte Diameter

\begin{tabular}{|c|c|c|c|}
\hline & No. studied & $\begin{array}{c}\text { Mean megakaryocytic } \\
\text { diameter* }\end{array}$ & $\begin{array}{l}\text { Factor for } \\
\text { multiple } \\
\text { counting error }\end{array}$ \\
\hline & & $\mu$ & \\
\hline Rat & 6 & $20.7 \pm 3.4$ & 7.0 \\
\hline Man & 18 & $20.8 \pm 3.3$ & 6.7 \\
\hline
\end{tabular}

* These values were obtained from Zenker's formaldehyde-fixed marrow which had undergone shrinkage of about $25 \%$ as compared with glutaraldehyde-fixed material. 
identical in the normal animal and human subject. Mean megakaryocytic diameter was shown to be the same in splenic sections as for marrow.

Using $20.7 \mu$ as the mean megakaryocyte diameter in the derived formula $(d / t)+1$, we found the average number of microtome cuts through the megakaryocyte was:

$$
\frac{\text { mean megakaryocyte diameter }}{\text { thickness of tissue section }}+1=\frac{20.7}{3}+1=7.9 \text {. }
$$

In order to assess the accuracy of this multiple counting correction, we found that the average number of cell slices counted in 50 serially sectioned megakaryocytes was 352 in rat marrow which gave a factor of 7.0 cuts/ cell, and 334 in human marrow which gave a factor of 6.7. The difference between measured and theoretical values was probably due to the fact that some of the smaller sections cut through the periphery of the megakaryocytes were not identifiable as such, thereby reducing the effective diameter of the cell. The difference in the multiple counting error between rat and human marrow was attributed to increased cell distortion in human material produced by the decalcification process.

Red cell precursors were also tested for "multiple counting" error by serial section studies. The incidence of duplicate counting on adjacent serial sections was determined to be only about $4 \% .^{7}$ Thus, it was not necessary to employ a correction factor in estimates of nucleated red cell numbers.

'Although the mean diameter of the nucleated red cells in Zenker's-fixed marrow sections was $4.8 \mu$, the "effective diameter" was less than $1 \mu$ because only cuts through the central portion of the nucleus were recognized as nucleated red cells. The theoretical duplicate counting would accordingly be about $15 \%$. The remaining discrepancy between theoretical $(15 \%)$ and emperic (4\%) duplicate counting was perhaps due to actual loss of pieces of the nucleus after sectioning or movement of nuclei in the soft blocking agent during cutting.
In the rat the total marrow ${ }^{54} \mathrm{Fe}$ activity at the time of sampling was determined by direct counting of the cleaned skeleton (4), and was found to be $33.2 \pm 1.8 \%$ of the injected dose in 10 normal male Sprague-Dawley rats weighing $250 \pm 10 \mathrm{~g}$ at $6 \mathrm{hr}$ after the injection of plasma-bound ${ }^{59} \mathrm{Fe}$.

In man the marrow activity at sampling time was considered to be $67 \%$ of the injected dose on the basis of ferrokinetic data (5). During the section preparation of rat marrow, less than $0.5 \%$ of radioiron activity was lost. However, in the preparation of human biopsy material considerable radioactivity was lost during decalcification. In order to correct for this loss, we made direct measurements of ${ }^{59} \mathrm{Fe}$ activity of each biopsy specimen before and after decalcification and checked the difference obtained against the activity remaining in the decalcification solution. ${ }^{8}$

\section{Calculations}

Total megakaryocytes $(M)$ are the sum of the marrow megakaryocytes $\left(M_{b}\right)$ and the splenic megakaryocytes $\left(M_{s}\right)$. Total bone marrow megakaryocytes $\left(M_{b}\right): M_{b}=$ $m\left(A_{b} / a\right)$, where $m=$ megakaryocytes in a single marrow section (corrected for "multiple counting") ; $a=$ activity of ${ }^{59} \mathrm{Fe}$ in the same marrow section; and $A_{b}={ }^{59} \mathrm{Fe}$ activity in the total bone marrow. Total splenic megakaryocytes $\left(M_{s}\right)$ were similarly calculated from the ratio of megaryocytes to radioactivity in a single section multiplied by the total radioactivity in the spleen. Likewise, the total nucleated erythroid cell number (E) was derived from the relationship of nucleated red cells to radioactivity in a section times the radioactivity in the entire bone marrow. ${ }^{9}$

${ }^{8}$ Armac Counter, Packard Instrument Co., Downers Grove, Ill.

9 The formula for total splenic megakaryocytes $\left(M_{s}\right)$ was: $M_{s}=m\left(A_{s} / a\right)$, and for total nucleated erythroid cell number $(E): E=e\left(A_{b} / a\right)$ where $m=$ megakaryocytes in a single splenic section (corrected for multiple

TABLE II

Relationship of Radioiron Activity and Cell Enumeration of Six Random Marrow Sections from a Single Sampling Site in the Rat

\begin{tabular}{|c|c|c|c|c|c|c|c|}
\hline \multirow[b]{3}{*}{ Section } & \multirow[b]{3}{*}{${ }^{59} \mathrm{Fe}$ activity/section } & \multicolumn{3}{|c|}{ Megakaryocytes } & & & \multirow[b]{3}{*}{$\begin{array}{l}\text { Nucleated red cells/ } \\
\text { megakaryocyte }\end{array}$} \\
\hline & & \multicolumn{2}{|c|}{ No./section } & \multirow[b]{2}{*}{$\begin{array}{l}\text { Activity/ } \\
\text { megakaryocyte }\end{array}$} & \multicolumn{2}{|c|}{ Nucleated red cells } & \\
\hline & & $\begin{array}{c}\text { Raw } \\
\text { count }\end{array}$ & $\begin{array}{l}\text { Corrected } \\
\text { count }\end{array}$ & & No./section & $\begin{array}{cc}\text { Activity/nucle- Nuc } & \text { ated red cell }\end{array}$ & \\
\hline & $c p m$ & & & $c p m$ & & $c p m \times 10^{-3}$ & \\
\hline 1 & 265 & 758 & (108) & 2.44 & 21,425 & 12.4 & 199 \\
\hline 2 & 257 & 698 & $(100)$ & 2.57 & 20,588 & 12.5 & 206 \\
\hline 3 & 242 & 736 & $(105)$ & 2.30 & 20.746 & 11.7 & 198 \\
\hline 4 & 264 & 732 & $(105)$ & 2.52 & 21,262 & 12.4 & 202 \\
\hline 5 & 271 & 758 & (108) & 2.50 & 22,233 & 12.2 & 206 \\
\hline 6 & 288 & 746 & (107) & 2.70 & 22,943 & 12.6 & 212 \\
\hline \multicolumn{2}{|c|}{ Mean } & & & $2.51 \pm 5.0 \%$ & & $12.3 \pm 2.5 \%$ & $204 \pm 2.5 \%$ \\
\hline
\end{tabular}


TABLE III

Relationship of Radioiron Activity and Cell Enumeration of Six Random Marrow Sections from a Single Sampling Site in Man

\begin{tabular}{|c|c|c|c|c|c|c|c|}
\hline \multirow[b]{3}{*}{ Section } & \multirow[b]{3}{*}{${ }^{59} \mathrm{Fe}$ activity/section } & \multicolumn{3}{|c|}{ Megakaryocytes } & & & \multirow[b]{3}{*}{$\begin{array}{l}\text { Nucleated red cells/ } \\
\text { megakaryocyte }\end{array}$} \\
\hline & & \multicolumn{2}{|c|}{ No./section } & \multirow[b]{2}{*}{$\begin{array}{l}\text { Activity/ } \\
\text { megakaryocyte }\end{array}$} & \multicolumn{2}{|c|}{ Nucleated red cells } & \\
\hline & & $\begin{array}{l}\text { Raw } \\
\text { count }\end{array}$ & $\begin{array}{l}\text { Corrected } \\
\text { count }\end{array}$ & & No./section & $\begin{array}{l}\text { Activity/nucle- } \\
\text { ated red cell }\end{array}$ & \\
\hline & $c p m$ & & & $c p m$ & & $c p m \times 10^{-3}$ & \\
\hline 1 & 54.4 & 922 & (138) & 0.39 & 34,180 & 1.59 & 248 \\
\hline 2 & 51.7 & 902 & (135) & 0.38 & 34,239 & 1.51 & 254 \\
\hline 3 & 47.3 & 813 & (122) & 0.39 & 29,136 & 1.62 & 239 \\
\hline 4 & 57.7 & 912 & (137) & 0.42 & 35,848 & 1.61 & 262 \\
\hline 5 & 58.1 & 917 & (137) & 0.42 & 36,482 & 1.59 & 266 \\
\hline 6 & 41.1 & 769 & (115) & 0.36 & 26,986 & 1.52 & 235 \\
\hline \multicolumn{2}{|c|}{ Mean } & & & $0.39 \pm 5.1 \%$ & & $1.57 \pm 3$. & $251 \pm 5.0 \%$ \\
\hline
\end{tabular}

\section{RESULTS}

Representative measurements of sectioned marrow from rats (Table II) indicated the suitability of such samples for relating radioactivity to megakaryocytes and nucleated red cells. The results obtained from random marrow sections were comparable for human material (Table III). Similar observations on marrow samples taken from several different sites in the rat (Table IV) demonstrated no apparent differences in cell distribution. Similar homogenous distribution of cell types was found in marrow obtained from multiple right and left iliac crest sites in three human subjects ( $\mathrm{SE}$ not greater than $5 \%$ ).

As shown in Table $\mathrm{V}$, the total number of counting) ; $e=$ number of nucleated red cells in a single marrow section; $a=$ activity of ${ }^{50} \mathrm{Fe}$ in the same section; $A_{s}=$ activity of ${ }^{80} \mathrm{Fe}$ in the entire spleen; and $A_{b}=\mathrm{ac}$ tivity of ${ }^{58} \mathrm{Fe}$ in the entire bone marrow. megakaryocytes in six normal Sprague-Dawley rats was determined to have a mean value of $11 \times$ $10^{6}$ megakaryocytes $/ \mathrm{kg}$ of which the spleen contributed less than $2 \%$ of the total. From similar observations on erythroid marrow, the number of nucleated red cells was also determined in these animals and the mean value was $2.6 \times 10^{9}$ cells/ $\mathrm{kg}$. The nucleated red cell: megakaryocyte ratio obtained from these calculations, or more directly from marrow counting, was $236: 1 .^{10}$

The total number of nucleated red cells per kilogram in the three hematologically normal human subjects (Table VI) was of the same order as in the rat. The total megakaryocyte number in these subjects was calculated to be $6.1 \times 10^{6} / \mathrm{kg}$, or about half that measured in the rat. The human nucleated red cell:megakaryocyte ratio was

10 Assuming a total nucleated cell number in rats of about $9 \times 10^{\circ}$ cells $/ \mathrm{kg}$, or about 1250 megakaryocytes $/ 10^{\circ}$ nucleated marrow cells.

TABLE IV

Constancy of Marrow Distribution in the Rat

\begin{tabular}{lccc}
\hline & \multicolumn{2}{c}{ Counts per minute } & $\begin{array}{c}\text { Nucleated red cell/ } \\
\text { megakaryocyte }\end{array}$ \\
\cline { 2 - 3 } Site & Megakaryocyte & Nucleated red cell & \\
Left tibia & $3.20 \pm 0.12$ & $\times 10^{-3}$ & $183 \pm 6.0$ \\
Left humerus & $3.02 \pm 0.14$ & $17.1 \pm 0.5$ & $176 \pm 4.0$ \\
Left femur & $3.05 \pm 0.10$ & $17.4 \pm 0.3$ & $175 \pm 5.0$ \\
Right femur & $3.04 \pm 0.17$ & $17.4 \pm 0.5$ & $174 \pm 7.0$ \\
Mean* & $3.08 \pm 2.8 \%$ & $17.3 \pm 1.3 \%$ & $177 \pm 4.1 \%$
\end{tabular}

* The SD of the values for six random sections at each site are shown. The SE of the average value appears with the mean. 
TABLE V

Total Megakaryocytes in the Rat

\begin{tabular}{|c|c|c|c|c|}
\hline Animal & $\begin{array}{l}\text { Megakaryocytes } \\
\text { in bone marrow }\end{array}$ & $\begin{array}{l}\text { Megakaryocytes } \\
\text { in spleen }\end{array}$ & $\begin{array}{c}\text { Total No. of } \\
\text { megakaryocytes }\end{array}$ & $\begin{array}{c}\text { Megakaryocytes } / \mathrm{kg} \\
\text { of body wt }\end{array}$ \\
\hline & \multicolumn{4}{|c|}{$\times 10^{6}$} \\
\hline 1 & 2.40 & 0.04 & 2.44 & 9.4 \\
\hline 2 & 3.23 & 0.12 & 3.35 & 13.1 \\
\hline 3 & 2.92 & 0.12 & 3.04 & 12.0 \\
\hline 4 & 2.25 & 0.11 & 2.36 & 9.3 \\
\hline 5 & 3.07 & 0.05 & 3.12 & 12.0 \\
\hline 6 & 2.42 & 0.07 & 2.49 & 9.9 \\
\hline \multicolumn{2}{|l|}{ Mean } & & & $11.0 \pm 1.6$ \\
\hline
\end{tabular}

directly measured to be $475: 1$, or about 600 megakaryocytes $/ 10^{6}$ nucleated marrow cells. ${ }^{11}$ To support the normality of these values, the nucleated red cell: megakaryocyte ratio in marrow sections from an additional 15 normal subjects was determined, and was found to be $465: 1$ with a SD of \pm 60 (range 325-575).

\section{DISCUSSION}

Three different methodological approaches have been successfully used to measure the total number of hematopoietic cells. The first technic involves the determination of the specific cell type per unit volume of marrow and the direct measurement of the total marrow volume. The technics involved are not only crude and laborious, but are obviously limited to animal study, although estimates have been derived for man (6). In the second approach, total marrow elements are calculated on the basis of the mitotic index of the particular cell type related to the time of mitosis, assuming a steady state of production and no cell loss within compartments. Despite the number of assumptions required and the inability to precisely

11 Assuming a total nucleated cell number in humans of $10 \times 10^{\circ} / \mathrm{kg}$ (11).

TABLE VI

Marrow Cell Quantitation in Human Subjects

\begin{tabular}{ccc}
\hline Subject & Nucleated red cells & Megakaryocytes \\
\hline & $\times 10^{\circ} / \mathrm{kg}$ & $\times 10^{6} / \mathrm{kg}$ \\
L. B. & 2.8 & 6.8 \\
M. L. & 3.2 & 6.1 \\
H. W. & 2.7 & 5.4 \\
Mean & 2.9 & 6.1 \\
\hline
\end{tabular}

measure mitosis time, the method has proven useful in normal man $(7,8)$. However, the time involved in making the observations and the requirement for a steady-state system render the approach unsuitable for studying many abnormal states. A more direct method employs the isotope dilution principle, with ${ }^{59} \mathrm{Fe}$ as a marrow label. In previous reports (9-11) the sampled marrow was measured as a suspension. Donohue, Reiff, Hanson, Betson, and Finch (12) observed cell-free radioactivity in the suspension preparations, and since they ascribed this radioactivity to red cell destruction they inserted an appropriate correction in their calculations of cell numbers.

TABLE VII

Quantitation of Nucleated Red Cells in Man

\begin{tabular}{|c|c|c|}
\hline Author & Method & $\begin{array}{l}\text { Nucleated } \\
\text { erythroid cells }\end{array}$ \\
\hline & & $\times 10^{9} / \mathrm{kg}$ \\
\hline Pegg (6) & Anatomic data & 2.5 \\
\hline Patt (7) & Mitosis data & 3.4 \\
\hline $\begin{array}{l}\text { Killmann, Cronkite, } \\
\text { Fliedner, and Bond ( } 8 \text { ) }\end{array}$ & Mitosis data & $3.5^{*}$ \\
\hline Suit (9) & $\begin{array}{l}\text { 59Fe-dilution, } \\
\text { cell suspension }\end{array}$ & 2.6 \\
\hline $\begin{array}{l}\text { Donohue, Gabrio, and } \\
\text { Finch (10) }\end{array}$ & $\begin{array}{l}{ }^{59} \mathrm{Fe} \text {-dilution, } \\
\text { cell suspension }\end{array}$ & $3.6 t$ \\
\hline Harrison (11) & $\begin{array}{l}{ }^{59} \mathrm{Fe} \text {-dilution, } \\
\text { cell suspension }\end{array}$ & $3.0 \S$ \\
\hline Present report & $\begin{array}{l}{ }^{59} \mathrm{Fe} \text {-dilution, } \\
\text { tissue section }\end{array}$ & 2.9 \\
\hline
\end{tabular}

* Given as "best estimate."

$\ddagger$ Without cell-free radioactivity correction.

$\S$ Total cellularity multiplied by the fraction of "erythroid precursor cells in the marrow. 
TABLE VIII

Quantitation of Normal Megakaryocyte No. in Man

\begin{tabular}{lccc}
\hline & \multicolumn{3}{c}{ Megakaryocytes* } \\
\cline { 2 - 4 } \multicolumn{1}{c}{ Study } & Smear & Suspension & Section \\
\hline & \multicolumn{3}{c}{$\times 10^{8 / \mathrm{kg}}$} \\
$\begin{array}{l}\text { Range of reported } \\
\text { values }(1,2,3)\end{array}$ & $0.6-56$ & $0.1-4.6$ & $20-200$ \\
$\begin{array}{l}\text { Gormsen (13) } \\
\text { Mellarme (14) }\end{array}$ & 5 & & \\
$\begin{array}{l}\text { Vogel and Bassen (15) } \\
\text { Nickerson and } \\
\quad \text { Sunderland (16) }\end{array}$ & 6 & 4.6 & \\
Custer and & & & $33.0(6.3) \S$ \\
$\quad$ Krumbhaar (17) & & & 6.1 \\
Present report & & & \\
\hline
\end{tabular}

* Values are expressed as magakaryocytes $/ \mathrm{kg}$ based on total nucleated cellularity of the bone marrow as $10 \times 10^{\circ} \%$ $\mathrm{kg}(11)$.

$\ddagger$ Corrected for "multiple counting" on basis of $4 \mu$ thick sections as reported (16).

$\S$ Corrected for "multiple counting" on basis of $6 \mu$ thick sections as reported (17).

Harrison (11) on the other hand, contended that the cell-free radioactivity represented loss of cytoplasm but not of nuclei from red cell precursors; he, therefore, made no such correction. There is no loss of cytoplasm when tissue is sectioned; thus, the close agreement of our data with those obtained by Harrison supports his contention (Table VII).

The data presented here on megakaryocytes are in agreement with some of the previous reports using marrow smear $(13,14)$ and suspension $(15)$ methods (Table VIII). Published studies employing section methods gave values four to five times greater than the present report $(16,17)$; however, if appropriate corrections are made for "multiple counting" (based on the reported tissue section thickness), the results are in good agreement with the present study.

\section{ACKNOWLEDGMENTS}

The author gratefully acknowledges the helpful suggestions given by Dr. C. A. Finch during the course of the study, and wishes to thank both Dr. Finch and Dr. Eloise Giblett for their review of the manuscript. Dr. George Marsaglia kindly served as mathematical consultant. The technical assistance of Mrs. Barbara Cheney and Mrs. Loretta Willis was greatly appreciated. This investigation was supported in part by U. S. Public Health Service research grant 5-RO1-He-06242 and Fellowship Grant 1-F3-He-32, 188-01. A portion of this work was conducted through the Clinical Research Center facility of the University of Washington supported by the National Institutes of Health (grant FR-37).

\section{REFERENCES}

1. Finch, C. A. 1961. Thrombokinetics. In Blood Platelets. Henry Ford Hospital International Symposium. 1960. S. A. Johnson, R. W. Monto, J. W. Rebuck, and R. C. Horn, editors. Little, Brown and Company, Boston. 629.

2. Berman, L., A. R. Alexrod, and E. S. Kumke. 1948. Estimation of megakaryocyte content of aspirated sternal marrow. Am. J. Clin. Pathol. 18: 898.

3. Pizzolato, P. 1948. Sternal marrow megakaryocytes in health and disease. Am. J. Clin. Pathol. 18: 891.

4. Cheney, B. A., K. Lothe, E. H. Morgan, S. K. Sood, and C. A. Finch. 1967. Internal iron exchange in the rat. Am. J. Physiol. 212: 376.

5. Hosain, F., G. Marsaglia, and C. A. Finch. 1967. Blood ferrokinetics in normal man. J. Clin. Invest. 46: 1 .

6. Pegg, D. E. 1962. A quantitative study of bone marrow grafting. Implications for human bone marrow infusion. Brit. J. Cancer. 16: 400.

7. Patt, H. M. 1957. A consideration of myeloiderythroid balance in man. Blood. 12: 777.

8. Killmann, S. A., E. P. Cronkite, T. M. Fliedner, and V. P. Bond. 1964. Mitotic indices of human bone marrow cells. III. Duration of some phases of erythrocytic and granulocytic proliferation computed from mitotic indices. Blood. 24: 267.

9. Suit, H. D. 1957. A technique for estimating the bone marrow cellularity in vivo using ${ }^{50} \mathrm{Fe}$. J. Clin. Pathol. 10: 267.

10. Donohue, D. M., B. W. Gabrio, and C. A. Finch. 1958. Quantitative measurement of hematopoietic cells of the marrow. J. Clin. Inest. 37: 1564.

11. Harrison, W. J. 1962. The total cellularity of the bone marrow in man. J. Clin. Pathol. 15: 254.

12. Donohue, D. M., R. H. Reiff, M. L. Hanson, Y. Betson, and C. A. Finch. 1958. Quantitative measurement of the erythrocytic and granulocytic cells of the marrow and blood. J. Clin. Invest. 37: 1571.

13. Gormsen, H. 1940. Diagnostic value of sternal puncture; review of literature in connection with personal investigations. Ugeskrift Laeger. 102: 991.

14. Mallarme, J. 1937. Le myelogramme normal et pathologique. Sang. 11: 804.

15. Vogel, P., and F. A. Bassen. 1939. Sternal marrow of children in normal and in pathologic states. $\mathrm{Am}$. J. Diseases Children. 57: 245.

16. Nickerson, D. A., and D. A. Sunderland. 1937. The histopathology of idiopathic thrombocytopenic purpura hemorrhagica. Am. J. Pathol. 13: 463.

17. Custer, R. P., and E. B. Krumbhaar. 1935. The histopathology of the hematopoietic tissues in hemophilia. An unexplored field. Am. J. Med. Sci. 189: 620 . 